\title{
STRUKTUR BIROKRASI DAN DISPOSISI DALAM PELAKSANAAN KAWASAN SEHAT BEBAS ASAP ROKOK DI SEKOLAH
}

\author{
Parmadi Sigit Purnomo, Totok Sundoro, Pramukti Dian S \\ Fakultas Program Studi Kesehatan Masyarakat STIKes Surya Global Yogyakarta \\ *Correspondence: parmadisigitpurnomo@gmail.com \\ Dikirim 07 Desember 2019; Diterima 10 Desember 2019; Dipublikasi Februari 2020
}

\begin{abstract}
Based on the Riskesdas Health Research and Development Agency in 2013, the Special Province of Yogyakarta tended to be high at 21.2\% for the proportion of the population aged over or equal to 10 years who smoked every day. One of the districts in the Yogyakarta Special Region that has a policy on non-smoking areas is Bantul Regency. The regulation regarding the non-smoking areas is regulated in the Bantul Regent's Regulation No. 18 of 2016 concerning Healthy Areas Non-Smoking (HANS). This study aims to determine the structure of the bureaucracy and disposition in the implementation of a Healthy Smoke Free Area in Schools. This research uses descriptive qualitative method. Data analysis using data reduction, data presentation, and drawing conclusions. The results of interviews about the bureaucratic structure in the implementation of the HANS found that there were no smoking procedures for smokers in schools. General rules are included in the school code of conduct in the form of a slogan / smoking ban. The disposition aspect possessed by the school could not be said to be good in the implementation of the HANS, it was evident that there were still school residents who still smoked in the school area and found cigarette putp in the school area. The conclusion of the research is that the bureaucratic structure does not yet exist and the disposition factor cannot be carried out properly so that it is expected that there will be a follow-up from the Government of Bantul Regency to be able to socialize Bantul Regent Regulation No. 18 of 2016 concerning Smoke-Free Healthy Areas in the school environment involving the role of the Health Office, BNNP and / or the Police and develop a culture of reporting and providing guarantees for reporters from the Principal, as well as making special regulations / SOPs for school residents who have a smoking habit.
\end{abstract}

Keywords: Healthy area, Cigarette, School, Bureaucratic structure, Disposition.

\section{PENDAHULUAN}

Persentase penduduk dunia yang mengkonsumsi tembakau menurut The Tobacco Atlas 3rd edition 2009 adalah sebanyak 57\% pada penduduk Asia dan Australia, 14\% pada penduduk Eropa Timur dan pecahan Uni Soviet, 12\% penduduk Amerika, 9\% penduduk Eropa Barat dan 8\% pada penduduk Timur Tengah serta Afrika. Sementara itu ASEAN merupakan sebuah kawasan dengan 10\% dari seluruh perokok dunia dan 20\% penyebab kematian global akibat tembakau. Persentase perokok pada penduduk di negara ASEAN tersebar di Indonesia (46,16\%), Filipina (16,62\%), Vietnam (14,11\%), Myanmar (8,73\%), Thailand (7,74\%), Malaysia (2,90\%), Disimpulkan bahwa masalah kesehatan tentang rokok masih ditemukan diberbagai Negara khususnya di Negara Indonesia yang menjadikan salah Kamboja (2,07\%), Laos (1,23\%), Singapura (0,39\%), dan Brunei (0,04\%). satu faktor penyebab angka kematian di suatu Negara(1).

Merokok dapat menimbulkan berbagai permasalahan dalam kehidupan baik dari aspek kesehatan, aspek ekonomi serta aspek sosial-budaya. World Health Organization memprediksi kematian di seluruh dunia karena produk tembakau akan melebihi delapan juta per tahun pada tahun 2030 dan 70\% korban berasal dari negara berkembang(2). Merokok tidak hanya 
membahayakan kesehatan si perokoknya saja, tetapi juga orang-orang yang ada di sekitarnya. Lebih dari 600.00o kematian di dunia terjadi pada perokok pasif pada tahun 2004 dan $75 \%$ di antaranya adalah perempuan dan anak(3).

Indonesia telah mencapai tingkat yang sangat memprihatinkan dalam konsumsi produk tembakau, terutama rokok. Data Kementerian Kesehatan menunjukkan prevalensi perokok dari 27\% pada tahun 1995 meningkat menjadi $36,3 \%$ pada tahun 2013. Tidak mengherankan apabila Indonesia berada pada urutan ketiga jumlah perokok terbanyak setelah Cina dan India. Lebih memprihatinkan lagi adalah kebiasaan buruk merokok juga meningkat pada generasi muda. Data Kemenkes menunjukkan bahwa prevalensi remaja usia 16-19 tahun yang merokok meningkat 3 kali lipat dari 7,1\% di tahun 1995 menjadi 20,5\% pada tahun 2014. Lebih mengejutkan adalah usia mulai merokok semakin muda (dini). Perokok pemula usia 10-14 tahun meningkat lebih dari 100\% dalam kurun waktu kurang dari 20 tahun, yaitu dari 8,9\% di tahun 1995 menjadi 18\% di tahun 2013(1).

Word Health Organization (WHO) menyebutkan bahwa rokok merupakan salah satu penyebab kematian terbesar di dunia. Diperkirakan hingga menjelang 2030 kematian akibat merokok akan mencapai 10 juta per tahunnya dan di negaranegara berkembang diperkirakan tidak kurang 70\% kematian yang disebabkan oleh rokok. Menurut data dari Dinas Kesehatan Bantul tahun 2014, bahwa prevalensi merokok penduduk DI Yogyakarta pada saat ini sebesar 29,8\%, dengan rerata 7 sampai 8 batang perhari dan jenis yang banyak digunakan adalah rokok kretek dengan filter $(55,6 \%)$, dimana sepertiga penduduk di Yogyakarta mulai merokok pada usia 15-19 tahun dan sebanyak 80.7\% merokok di dalam rumah ketika bersama anggota keluarga lain, yang mengakibatkan anggota keluarga menjadi perokok pasif.

Berdasarkan Badan Penelitian dan Pengembangan Kesehatan Riskesdas tahun 2013, perilaku merokok penduduk 15 tahun keatas masih belum terjadi penurunan dari 2007 ke 2013, cenderung meningkat dari 34,2 persen tahun 2007 menjadi 36,3 persen tahun 2013. 64,9 persen laki-laki dan 2,1 persen perempuan masih menghisap rokok tahun 2013. Ditemukan 1,4 persen perokok umur 10-14 tahun, 9,9 persen perokok pada kelompok tidak bekerja, dan 32,3 persen pada kelompok kuintil indeks kepemilikan terendah. Sedangkan rerata jumlah batang rokok yang dihisap adalah sekitar 12,3 batang, bervariasi dari 10 batang di DI Yogyakarta(1)

Perdebatan panjang terhadap perlunya kebijakan pengendalian tembakau di Indonesia sebetulnya tidak perlu terjadi mengingat dampak kesehatan yang diakibatkan penggunaan tembakau atau kebiasaan merokok. Pada tahun 2001, angka kejadian akibat penyakit yang berkaitan dengan kebiasaan merokok yang dilaporkan di Indonesia adalah 22,6\% atau 427,948 kematian(4). Insidensi kanker paru pada laki-laki di tahun 2001 menunjukkan 20 per 100.000 ribu penduduk, sementara pada wanita 6,8 per 100.000(5). Penyebab kematian nomor 1 di Indonesia pada tahun 1999 adalah penyakit sistem sirkulasi, termasuk di dalamnya adalah penyakit kardiovaskular(6). Kebiasaan merokok merupakan salah satu faktor risiko kanker paru dan penyakit kardiovaskular(7).

Salah satu upaya untuk menanggulangi masalah tersebut adalah dengan menerapkan 6 Paket Intervensi Kebijakan "Cost-Effective" MPOWER untuk mengendalikan konsumsi rokok, salah satunya yaitu perlindungan terhadap paparan asap rokok di lingkungan (Protect People from Tobacco Smoke), kemudian lahirlah Undang-Undang Kawasan Tanpa Rokok (UU KTR) atau Kawasan Bebas Asap Rokok di beberapa negara di dunia. Beberapa negara dan kota di dunia telah membuktikan bahwa UU KTR yang diikuti dengan penegakan hukum yang ketat, memiliki dukungan dan tingkat kepatuhan masyarakat yang cukup tinggi seperti Irlandia (90\%), Uruguay (80\%), New York (75\%), California (75\%), dan New Zealand $(70 \%)(8)$.

Salah satu kabupaten di Daerah Istimewa Yogyakarta yang memiliki kebijakan tentang kawasan tanpa rokok adalah Kabupaten Bantul. Peraturan mengenai Kawasan Tanpa Rokok tersebut diatur dalam Peraturan Bupati Bantul No. 18 Tahun 2016 Tentang Kawasan Sehat Bebas Asap Rokok(9). Peraturan tersebut berlaku sangat jelas di lingkungan sekolah hal ini juga didukung dengan adanya Peraturan Menteri Pendidikan dan Kebudayaan Republik Indonesia Nomor 64 tahun 2015 tentang Kawasan Tanpa Rokok di Sekolah. Untuk mewujudkan perilaku hidup bersih dan sehat didukung dengan penciptaan lingkungan sekolah yang bebas dari 
pengaruh rokok dan dalam rangka memberikan perlindungan secara menyeluruh, terpadu dan berkesinambungan dari dampak buruk rokok, perlu menciptakan kawasan tanpa rokok di lingkungan sekolah(10).

Melihat tingginya prevalensi penduduk yang merokok $(34,7 \%)$, dan remaja berumur 15-24 tahun (18,6\%) yang telah merokok tiap hari (11). Indonesia pun sudah memiliki peraturan yang menyebutkan perlunya kawasan tanpa rokok atau kawasan bebas asap rokok. Undang- Undang (UU) No. 23 Tahun 1997 tentang Pengelolaan Lingkungan Hidup yang mulai mencetuskan area bebas asap rokok untuk lingkungan sehat. Namun, peraturan Kawasan Tanpa Rokok (KTR) di Indonesia cenderung kurang ditegakkan dan tidak tegas. Hasil penelitian di Kota Semarang, yang dilakukan di kampus Fakultas Kedokteran Universitas Diponegoro yang menerapkan peraturaan KTR, diperoleh bahwa hampir sebagian mahasiswa dan karyawannya (44,0\%) tidak patuh(12). Beberapa penelitian dan teori telah diketahui bahwa terdapat banyak faktor yang mempengaruhi kepatuhan selain faktor merokok itu sendiri atau ketergantungan nikotin(13). Menurut Green (1980) ada beberapa faktor antara lain pengetahuan, sikap, lingkungan sosial, penegakan hukum atau sanksi dan pengawasan(14).

George C Edwards III mengajukan empat variabel atau faktor yang mempengaruhi keberhasilan pelaksanaan kebijakan, dua diantaranya adalah struktur birokrasi dan disposisi(15). Variabel-variabel tersebut tidak saja selalu berdiri sendiri-sendiri, namun dapat saja saling terkait satu sama lain. Birokrasi merupakan struktur organisasi yang bertugas untuk mengimplementasikan kebijakan memiliki pengaruh yang signifikan terhadap implementasi kebijakan. Untuk mendukung keberhasilan implementasi kebijakan diperlukan sebuah prosedur operasional yang standar. SOP diperlukan sebagai pedoman operasional bagi setiap implementor kebijakan. Selain itu, struktur organisasi birokrasi juga harus dirancang sedemikian rupa untuk menghindari prosedur yang terlalu panjang dan berbelit-belit serta tentunya untuk memudahkan pengawasan. Disposisi yang dimaksud adalah menyangkut watak dan karakteristik yang dimiliki oleh implementor, seperti komitmen, kejujuran dan sifat demokratis. Disposisi yang dimiliki oleh implementor menjadi salah satu variabel penting dalam implementasi kebijakan. Apabila implementor memiliki disposisi yang baik, maka akan dapat menjalankan kebijakan dengan baik sebagaimana yang diharapkan oleh pembuat kebijakan. Sudah menjadi rahasia umum, bagaimana sebuah kebijakan yang bagus kadangkala harus kandas di tengah jalan, ataupun salah sasaran karena perilaku dari implementor kebijakan. Tujuan dari penelitian ini adalah untuk mengetahui struktur birokrasi dan disposisi dalam pelaksanaan Kawasan Sehat Bebas Asap rokok di sekolah.

\section{METODE PENELITIAN}

Penelitian deskriptif dengan pendekatan kualitatif terkait struktur birokrasi dan disposisi dalam pelaksanaan kawasan sehat asap rokok di sekolah. Stuktur birokrasi merupakan struktur organisasi yang bertugas untuk mengimplementasikan kebijakan, sedangkan disposisi adalah watak dan karakteristik yang dimiliki oleh implementor, seperti komitmen, kejujuran dan sifat demokratis. Metode studi kasus (case study) yang mengambil sampel dari populasi dan menggunakan panduan wawancara dan panduan observasi dan telusur dokumen sebagai instrumen pengumpul data. Studi kasus adalah suatu serangkaian kegiatan ilmiah yang dilakukan secara intensif, terincidan mendalam tentang suatu program, peristiwa, dan aktivitas, baik pada tingkat perorangan, sekelompok orang, lembaga, atau organisasi untuk memperoleh pengetahuan mendalam tentang peristiwa tersebut. Di dalam penelitian ini, peneliti melakukan wawancara terstruktur yaitu dalam melakukan wawancara, peneliti telah menyiapkan instrumen penelitian berupa pertanyaan-pertanyaan tertulis. Informan utama adalah Kepala Sekolah sedangkan informan pendukung dari karyawan dan siswa sekolah. Lokasi penelitian di MAN 3 Bantul Yogyakarta. Dengan Teknik pengumpulan data yaitu Observasi, wawancara dan dokumentasi. Teknik pengolahan data yaitu editing, klasifikasi dan pemberian kode. 
Metode analisis data nya menggunakan reduksi data melalui proses pemilihan, pemusatan perhatian pada penyederhanaan, pengabstrakan, dan transformasi data "kasar" yang muncul dari catatan-catatan tertulis di lapangan, penyajian data, dilanjutkan dengan menarik kesimpulan. Waktu Penelitian adalah mulai bulan April 2019 sampai dengan bulan Agustus 2019.

\section{HASIL DAN PEMBAHASAN}

Peneliti melakukan proses pengumpulan data dengan metode wawancara, selanjutnya hasil wawancara juga dilengkapi dengan data hasil observasi secara langsung yang telah dilakukan di lingkungan MAN 3 Bantul dan dokumentasi. Hal tersebut untuk mengetahui struktur birokrasi dan disposisi dalam pelaksanaan Kawasan Sehat Bebas Asap rokok di Sekolah. Wawancara dilakukan terhadap 13 (tiga belas) orang narasumber di MAN 3 Bantul. Selanjutnya untuk mengetahui karakteristik subyek penelitian, maka dapat dilihat pada tabel 1.

Tabel 1. Karakteristik Informan Penelitian

\begin{tabular}{cccccc}
\hline \multirow{2}{*}{ Jenis Kelamin \& Usia } & \multicolumn{6}{c}{ TINGKAT PENDIDIKAN } & TOTAL \\
\cline { 2 - 6 } & S2 & S1 & SLTA & SLTP & \\
\hline Laki - laki & 2 & 3 & 2 & 2 & 9 \\
\hline $15-23$ & & & & 2 & 2 \\
\hline $24-32$ & & & 2 & & 2 \\
\hline $33-41$ & 2 & 2 & & & 1 \\
\hline $42-60$ & 2 & & & 2 & 4 \\
\hline Perempuan & & & & 2 & 2 \\
\hline $15-23$ & 1 & & & & 1 \\
\hline $24-32$ & 1 & & & & 1 \\
\hline $42-60$ & 4 & 3 & 2 & 4 & 13 \\
\hline Grand Total & & & & & \\
\hline
\end{tabular}

Pada tabel 1 disebutkan bahwa karakteristik informan penelitian dalam kategori jenis kelamin disebutkan laki-laki ada 9 orang yang terbagi menurut usia 15-23 tahun sebanyak 2 orang, usia 24-32 tahun sebanyak 2 orang, usia 33-41 tahun sebanyak 1 orang dan usia 42-6o tahun sebanyak 4 orang. Sedangkan informan dengan jenis kelamin perempuan sebanyak 4 orang yang terbagi berdasarkan kelompok usia 15-23 tahun sebanyak 2 orang, usia 24-32 tahun sebanyak 1 orang dan usia 42-6o tahun sebanyak 1 orang.

Karakteristik informan penelitian berdasarkan tingkat pendidikan terakhir untuk jenjang S2 sebanyak 4 orang terbagi berdasarkan jenis kelamin laki-laki sebanyak 2 orang dan perempuan sebanyak 2 orang. Tingkat pendidikan jenjang S1 sebanyak 3 orang yang semuanya dengan jenis kelamin laki-laki sebanyak 3 orang. Tingkat pendidikan jenjang SLTA sebanyak 2 orang dari kategori laki-laki dan tingkat pendidikan jenjang SLTP sebanyak 4 orang terbagi dari informasi jenis kelamin laki-laki sebanyak 2 orang dan perempuan 2 orang.

Peneliti melakukan pengamatan langsung dan mencari bukti-bukti terkait implemantasi sekolah sebagai tempat kawasan sehat bebas asap rokok yang disajikan pada tabel 2. 
Tabel 2. Hasil Observasi Implementasi Kebijakan Kawasan

Sehat Bebas Asap Rokok di MAN 3 Bantul Tahun 2019

\begin{tabular}{clcc}
\hline No. & \multicolumn{1}{c}{ Indikator } & Ya/Ada & Tidak \\
\hline $\mathbf{1}$ & $\begin{array}{l}\text { Kebijakan atau aturan tertulis yang dibuat sekolah } \\
\text { tentang larangan merokok di area sekolah }\end{array}$ & $\sqrt{ }$ & $\sqrt{ }$ \\
\hline 2 & $\begin{array}{l}\text { Program kegiatan sekolah dalam mendukung } \\
\text { Peraturan Bupati Bantul Nomor 18 Tahun 2016 } \\
\text { tentang Kawasan Sehat Bebas Asap Rokok }\end{array}$ & $\sqrt{ }$ \\
\hline 3 & $\begin{array}{l}\text { Surat Keputusan Kepala Sekolah tentang Tim } \\
\text { Khusus atau Satgas yang bertugas mensukseskan } \\
\text { Peraturan Bupati Bantul Nomor 18 Tahun 2016 } \\
\text { tentang Kawasan Sehat Bebas Asap Rokok }\end{array}$ & & \\
\hline 4 & $\begin{array}{l}\text { Sosialisasi Peraturan Bupati Bantul Nomor 18 } \\
\text { Tahun 2016 tentang kawasan sehat bebas asap } \\
\text { rokok kepada staf/murid/santri/pengurus lain. }\end{array}$ & $\sqrt{ }$ \\
\hline 5 & $\begin{array}{l}\text { Pengumuman atau tanda yang menyatakan } \\
\text { Bahwa sekolah adalah tempat merupakan Kawasan } \\
\text { Sehat Bebas Asap Rokok }\end{array}$ & $\sqrt{ }$ \\
\hline 6 & Orang merokok di area internal sekolah & \\
\hline 7 & Terdapat Asbak/Korek Api /pemantik & $\sqrt{ }$ \\
\hline 8 & Ditemukan puntung rokok & $\sqrt{ }$ \\
\hline 9 & Ditemukan adanya iklan rokok & $\sqrt{ }$ \\
\hline 10 & Ditemukan adanya penjual rokok di area KSBAR & \\
\hline 11 & Terdapat tempat khusus untuk merokok & \\
\hline
\end{tabular}

Hasil observasi terkait implementasi kebijakan kawasan sehat bebas asap rokok di MAN 3 Bantul Tahun 2019 disampaikan bahwa MAN 3 Bantul belum membuat suatu kebijakan tertulis yang ditandatangani Kepala Sekolah tentang larangan bagi warga sekolah untuk tidak merokok dilingkungan area sekolah. Untuk mendukung kebijakan Bupati Bantul tentang Kawasan Sehat Bebas Asap Rokok, Kepala Sekolah belum membuat program kerjanya namun saat ini MAN 3 Bantul sudah pernah melakukan sosialisasi Peraturan Bupati Bantul Nomor 18 Tahun 2016 tentang kawasan sehat bebas asap rokok kepada staf/murid/santri/pengurus lain pada saat upaca bendera dan ada dikelas.

Terpasang pengumuman atau tanda yang menyatakan bahwa sekolah ini merupakan kawasan Bebas Asap Rokok atau dilarang merokok yang terpasang di depan pintu masuk sekolah, UKS dan Perpustakaan. Saat observasi lapangan di MAN 3 Bantul, peneliti tidak menemukan orang merokok di kawasan sekolah, tidak menemukan Asbak/Korek Api/pemantik, namun peneliti menemukan puntung rokok di kamar mandi dan parkir sekolah, dan pemeliti menemukan penjual rokok di diluar sekitar sekolah. Sekolah juga tidak menyediakan tempat khusus untuk merokok.

Birokrasi merupakan salah satu bahan yang paling sering bahkan secara keseluruhan menjadi pelaksana kebijakan. Birokrasi baik secara sadar atau tidak sadar memilih bentuk-bentuk organisasi untuk kesepakatan kolektif, dalam rangka memecahkan masalah-masalah sosial dalam kehidupan modern. Aspek struktur birokrasi ini akan dilihat tentang keberadaan aturan tegas dari pihak sekolah tentang prosedur/SPO larangan merokok di area sekolah bagi warga sekolah yang perokok. Dengan dipenuhi aspek struktur birokrasi ini melalui adanya Standar Prosedur Operasional yang jelas diharapkan kebijakan larangan merokok akan dipatuhi oleh seluruh warga sekolah yang berstatus perokok. 
Tabel 3. Uji Kredibilitas Triangulasi Sumber tentang Struktur Birokrasi dalam Implementasi Kebijakan Kawasan Sehat Bebas Asap Rokok di MAN 3 Bantul

\section{Pernyataan $\quad$ Jawaban}

$\begin{array}{lcc}\text { Belum ada SPO yang dibuat, sehingga } & \text { Ya } & \text { Tidak } \\ \text { pelaksanaan kawasan sehat bebas asap rokok } & & \text { o (o\%) } \\ \text { secara umum dapat dilaksanakan oleh seluruh } & 13(100 \%) & \\ \text { warga sekolah baik guru, karyawan, dan siswa } & & \end{array}$

Berdasarkan hasil uji triangulasi sumber pada tabel 3, terdapat kesesuaian antar informan terkait struktur birokrasi dalam menjalankan kebijakan kawasan tanpa rokok, yakni suatu SPO bagi warga perokok yang dibuat oleh pimpinan. Seluruh informan menyampaikan bahwa di MAN 3 Bantul belum tersedia prosedur tertulis atau SPO yang dibuat oleh kepala sekolah tentang larangan merokok diarea sekolah atau kawasan sekolah bebas asap rokok bagi warga perokok.

Selanjutnya hasil tersebut dicek kembali dengan uji triangulasi teknik yang hasilnya pada tabel 4:

Tabel 4. Uji Kredibilitas Triangulasi Teknik tentang Struktur Birokrasi dalam Implementasi Kebijakan Kawasan Sehat Bebas Asap Rokok di MAN 3 Bantul Tahun 2019

\begin{tabular}{|c|c|c|c|}
\hline Pernyataan & $\begin{array}{c}\text { Hasil } \\
\text { Observasi }\end{array}$ & $\begin{array}{c}\text { Hasil } \\
\text { Wawancara }\end{array}$ & Hasil Dokumentasi \\
\hline $\begin{array}{lr}\text { SPO melarang } \\
\text { baik } & \text { guru, } \\
\text { karyawan, siswa, } \\
\text { dan tamu } \\
\text { merokok } \\
\text { lingkungan } \\
\text { sekolah. }\end{array}$ & $\begin{array}{c}\text { Tidak } \\
\text { ditemukan bukti } \\
\text { adanya SPO } \\
\text { tertulis dari } \\
\text { kepala sekolah } \\
\text { tentang } \\
\text { larangan } \\
\text { merokok bagi } \\
\text { guru, karyawan, } \\
\text { siswa, tamu } \\
\text { yang perokok. }\end{array}$ & $\begin{array}{c}\text { Belum ada } \\
\text { SPO/Prosedur } \\
\text { Kepala sekolah } \\
\text { terkait larangan } \\
\text { merokok bagi guru, } \\
\text { karyawan, siswa, } \\
\text { tamu di lingkungan } \\
\text { sekolah }\end{array}$ & $\begin{array}{c}\text { Ada larangan merokok } \\
\text { berupa slogan/stiker di } \\
\text { depan pintu masuk } \\
\text { sekolah, perpustakaan } \\
\text { dan UKS, namun belum } \\
\text { ada SPO yang mengatur } \\
\text { bagi warga yang } \\
\text { merokok }\end{array}$ \\
\hline
\end{tabular}

Sesuai dengan tabel 4 hasil triangulasi teknik melalui wawancara, observasi, dan juga dokumentasi dapat diketahui bahwa dalam mengimplementasikan kebijakan kawasan sehat bebas asap rokok, MAN 3 Bantul belum membuat SPO khusus sebagai pedoman pelaksanaan. Pihak sekolah hanya mengacu pada tata tertib siswa, guru, dan karyawan yang telah ada sebelumnya. Larangan merokok hanya berupa slogan atau stiker yang ditempel di depan pintu masuk sekolah, UKS dan perpustakaan.

Implementasi Kebijakan Kawasan Sehat Besas Asap rokok di MAN 3 Bantul Yogyakarta belum dapat dikatakan baik karena belum terdapat peraturan khusus/SPO dalam melaksanakan kebijakan kawasan Sehat bebas asap rokok. Peraturan yang ada hanya sebatas tata tertib yang telah ada berupa stiker/poster. Birokrasi merupakan struktur organisasi yang bertugas untuk mengimplementasikan kebijakan memiliki pengaruh yang signifikan terhadap implementasi kebijakan. Untuk mendukung keberhasilan implementasi kebijakan diperlukan sebuah prosedur operasional yang standar. SOP diperlukan sebagai pedoman operasional bagi setiap implementor kebijakan. Selain itu, struktur organisasi birokrasi juga harus dirancang sedemikian rupa untuk menghindari prosedur yang terlalu panjang dan berbelit-belit serta tentunya untuk memudahkan pengawasan (Suharno, 2013)(17). Salah satu dari aspek tersebut adalah adanya prosedur operasi yang 
standar yang menjadi pedoman dalam pelaksanaan kebijakan yang ada(16). Dalam aspek ini, pihak MAN 3 Bantul belum memiliki standar operasional prosedur yang digunakan dalam melaksanakan kebijakan KSBAR. Belum adanya SOP yang khusus menyebabkan keadaan tidak kondusif terhadap pelaksanaan suatu peraturan, maka hal ini akan menyebabkan ketidakefektifan dan menghambat jalannya pelaksanaan kebijakan. Selama ini dalam pelaksanaannya, pihak sekolah mengarah pada peraturan tata tertib baik tata tertib bagi guru, karyawan, dan siswa. Sedangkan bagi bidang kesiswaan dalam mengkoordinasi adanya peraturan tersebut bekerja sama dengan organisasi OSIS.

Kesimpulan dari uraian tersebut yakni belum adanya SOP yang jelas dalam melaksanakan kebijakan kawasan sehat bebas asap rokok di MAN 3 Bantul bisa menghambat proses pelaksanaan kebijakan, terutama bagi para pelaksana seperti guru dan karyawan dikarenakan tidak ada pihak khusus yang ditunjuk untuk bertanggung jawab dalam mengawasi pelaksanaan kebijakan kawasan tanpa rokok tersebut.

Disposisi adalah menyangkut watak dan karakteristik yang dimiliki oleh implementor, seperti komitmen, kejujuran dan sifat demokratis. Disposisi yang diharapkan dalam implementasi kebijakan kawasan sehat bebas asap rokok di sekolah ini yakni karakteristik yang ada pada diri pelaksana yakni warga sekolah dalam menyikapi adanya kebijakan tersebut. Dalam menyusun kebijakan tentang larangan merokok diharapkan pihak sekolah/pembuat kebijakan disekolah dapat melibatkan warga yang perokok dan yang tidak perokok dalam membangun komitmen bersama untuk bersama-sama tidak merokok diarea sekolah dan terbentuk budaya saling menegur apabila dijumpai warga sekolah yang merokok di area lingkungan sekolah.

Sikap yang ditunjukkan dalam menanggapi kebijakan kawasan tanpa rokok di lingkungan Man 3 Bantul digambarkan dalam tabel uji kredibilitas triangulasi sumber adalah seperti pada tabel 5 berikut ini:

Tabel 5. Uji Kredibilitas Triangulasi Sumber tentang Disposisi Dalam Implementasi Kebijakan Kawasan Sehat Bebas Asap Rokok di Man 3 Bantul Tahun 2019

\begin{tabular}{lcc}
\hline \multicolumn{2}{c}{ Pernyataan } & \multicolumn{2}{c}{ Jawaban } \\
\hline Watak/Karakteristik Informan dalam & Ya & Tidak \\
\cline { 2 - 3 } $\begin{array}{l}\text { menyikapi kebijakan KSBAR di MAN 3 } \\
\text { Bantul untuk tetap merokok } \\
\text { dilingkungan internal sekolah }\end{array}$ & & 9 orang \\
\hline Tindakan yang dilakukan saat melihat & $\begin{array}{c}\text { 5 orang aktif } \\
\text { ada warga di sekolah yang merokok }\end{array}$ & $\begin{array}{c}\text { 8 orang pasif } \\
\text { (diam) }\end{array}$ \\
\hline
\end{tabular}

Berdasarkan tabel 5 tersebut dapat disimpulkan bahwa disposisi pelaksana kebijakan kawasan sehat bebas asap rokok di MAN 3 Bantul belum sejalan dengan kebijakan yang telah ditetapkan. Terbukti masih ada 4 (empat) informan yang menyampaikan bahwa mereka akan tetap merokok dilingkungan internal sekolah meskipun sudah ada kebijakan larangan merokok dan tindakan pasif dari 8 (delapan) informan saat melihat ada warga di area sekolah yang merokok artinya belum ada upaya menegur atau mengingatkan bahwa sekolah merupakan tempat area kawasan bebas asap rokok.

Tabel 6. Uji Kredibilitas TriangulasiTeknik tentang Disposisi dalam Implementasi Kebijakan Kawasan Sehat Bebas Asap Rokok di MAN 3 Bantul Tahun 2019

\begin{tabular}{|c|c|c|c|}
\hline Pernyataan & $\begin{array}{c}\text { Hasil } \\
\text { Observasi }\end{array}$ & $\begin{array}{c}\text { Hasil } \\
\text { Wawancara }\end{array}$ & $\begin{array}{c}\text { Hasil } \\
\text { Dokumentasi }\end{array}$ \\
\hline $\begin{array}{l}\text { Watak/Karakteristik } \\
\text { Informan dalam menyikapi } \\
\text { kebijakan KSBAR di MAN } 3 \\
\text { Bantul untuk tetap } \\
\text { merokok dilingkungan } \\
\text { internal sekolah }\end{array}$ & $\begin{array}{l}\text { Ditemukan putung } \\
\text { rokok di area } \\
\text { sekolah (diparkir \& } \\
\text { ditoilet) }\end{array}$ & $\begin{array}{c}\text { Sebagian } \\
\text { informan tetap } \\
\text { merokok diarea } \\
\text { sekolah }\end{array}$ & $\begin{array}{l}\text { Adanya putung } \\
\text { rokok di area } \\
\text { sekolah (diparkir } \\
\quad \text { \& ditoilet) }\end{array}$ \\
\hline
\end{tabular}


Tabel 6 menunjukkan bahwa terdapat kesesuaian antara hasil wawancara, observasi, dan juga dokumentasi mengenai faktor disposisi dalam menyikapi pelaksanaan peraturan tentang kawasan tanpa rokok di MAN 3 Bantul yaitu belum ada kepatuhan warga sekolah dalam menerapkan kebijakan tentang KSBAR, terbukti ditemukannya putung rokok di area sekolah.

Disposisi adalah watak dan karakteristik yang dimiliki oleh implementor, seperti komitmen, kejujuran, dan sifat demokratis. Apabila implementor memilikidisposisi yang baik, maka dia akan dapat menjalankan kebijakan dengan baik seperti apa yang diinginkan oleh pembuat kebijakan. Ketika implementor memiliki sikap atau perspektif yang berbeda dengan pembuat kebijakan, maka proses implementasi kebijakan juga menjadi tidak efektif(17). Begitu pula dengan pelaksanaan kebijakan kawasan sehat bebas asap rokok di MAN 3 Bantul dibutuhkan sikap yang sesuai dengan apa yang telah ditetapkan. Terutama sikap kepala sekolah sebagai pimpinan atau pihak yang bertanggungjawab mengenai adanya kebijakan tersebut. Dilihat dari aspek disposisi, masih ada beberapa pihak yang memiliki perbedaan pendapat mengenai kebijakan kawasan sehat bebas asap rokok di sekolah.

Berdasarkan hasil wawancara dan observasi terdapat pihak yang sangat mendukung kebijakan tersebut dan ada juga pihak yang menyatakan mendukung namun masih saja melanggar peraturan yang ditetapkan. Hal lain menunjukkan bahwa terdapat sikap pasif kepada pihak yang melanggar adanya kebijakan tersebut. Hal tersebut dikarenakan pihak-pihak yang melanggar merupakan sosok yang lebih senior sehingga menimbulkan rasa canggung ketika ingin mengingatkan atau menegur.

Hasil observasi yang dilakukan oleh peneliti, tidak ditemukan area khusus bagi perokok meskipun tidak secara jelas larangan pengadaan area tersebut, tidak juga ditemukan adanya asbak namun ditemukan puntung rokok menunjukkan bahwa kebijakan tentang KSBAR belum dipatuhi. Pelaksanaan kawasan sehat bebas asap rokok harus sejalan tidak hanya dengan pelaksana mengerti dan tahu akan tujuan dan sasaran dari peraturannya saja, namun perlu kemauan untuk melaksanakankan kebijakan tersebut. Berdasarkan hal tersebut, aspek disposisi yang dimiliki oleh pelaksana di MAN 3 Bantul kurang dalam melaksanakan kebijakan kawasan sehat bebas asap rokok di sekolah.

Budaya untuk tidak merokok di area kawasan sehat bebas asap rokok tentunya akan berhasil perlu adanya dukungan pimpinan atau pihak terkait dalam memberikan sosialisasi atau deklarasi yang dilakukan secara terus menerus kepada warga di lingkungan sekolah. Deklarasi kawasan bebas asap rokok adalah salah satu upaya yang dilakukan dengan tujuan memiliki tempat bebas asap rokok untuk menciptakan kota yang sehat. Desi Nurfita, dkk (2019) meneliti tentang Evaluasi Program Deklarasi Daerah Asap Untuk Menciptakan Kota Yang Sehat Di Puskesmas Gondokusuman. Tujuan penelitian ini untuk memberikan deskripsi dan analisis pelaksanaan program deklarasi area bebas asap rokok di Puskesmas Gondokusuman. Berdasarkan hasil analisis, input program dianggap baik. Selanjutnya, proses deklarasi area bebas-rokok dilihat dari peran komunitas, respon masyarakat, dan laporan. Variabel output diamati dari komitmen, dampak terhadap masyarakat, dan kelengkapan laporan. Sejauh ini, output program dianggap positif(18). Kesimpulannya adalah kegiatan deklarasi kawasan sehat asap rokok merupakan salah satu program yang dapat membantu membudayakan untuk tidak merokok di sekolah sekaligus mensukseskan pelaksanaan kebijakan pemerintah terhadap larangan merokok di lingkungan sekolah.

\section{KESIMPULAN DAN SARAN}

Struktur birokrasi dan disposisi merupakan aspek penting dalam mendukung implementasi kebijakan kawasan sehat bebas asap rokok di sekolah. Dengan belum tersedianya peraturan khusus/SPO dalam pelaksanaan kebijakan sebagai aspek pendukung struktur birokrasi dan belum adanya bentuk sangsi atau teguran bagi yang melanggar sebagai aspek disposisi menyebabkan kebijakan dalam implementasi kawasan sehat bebas asap rokok di sekolah belum dapat dijalankan 
dengan baik. Terbukti masih adanya warga sekolah yang masih merokok di area lingkungan sekolah. Pelaksanaan kawasan sehat bebas asap rokok harus sejalan tidak hanya dengan pelaksana mengerti dan tahu akan tujuan dan sasaran dari peraturannya saja, namun perlu kemauan untuk melaksanakankan kebijakan tersebut. Melakukan sosialisasi dan deklarasi kawasan sehat asap rokok di sekolah merupakan salah satu upaya mendukung aspek struktur birokrasi dan disposisi dalam melaksanakan suatu kebijakan. Dengan demikian diharapkan pihak sekolah atau institusi pendidikan untuk dapat mempertimbangkan aspek struktur birokrasi dan disposisi dalam mengimplementasikan kebijakan Pemerintah tentang Kawasan Sehat Bebas Asap Rokok di Sekolah.

\section{REFERENSI :}

1. Kemenkes RI., 2013. Riset Kesehatan Dasar. Jakarta: Badan Penelitian dan Pengembangan.

2. Bustan MN. Epidemiologi Penyakit Tidak Menular. Jakarta: Rineka Cipta; 2007.

3. Tobacco Atlas. [cited 202014 Februari]; Available from www.tobaccoatlas.org.

4. Prabandari, Y. S. (2009). Kawasan tanpa rokok sebagai alternatif pengendalian tembakau studi efektivitas penerapan kebijakan kampus bebas rokok terhadap perilaku dan status merokok mahasiswa di fakultas kedokteran UGM, Yogyakarta. Jurnal Manajemen Pelayanan Kesehatan, 12(04)

5. Mackay, J., Jemal, A., Lee, N. C., \& Parkin, M. (2006). The Cancer Atlas. 2006 American Cancer Society 1599 Clifton Road NE, Atlanta, Georgia 30329, USA. Can also be accessed at www. cancer.org.

6. Departemen Kesehatan Indonesia. Profil Kesehatan Indonesia 1999. Pusat Data Kesehatan, Depkes RI, Jakarta, 1999.

7. Mackay, J., Eriksen, M., \& Eriksen, M. P. (2002). The tobacco atlas. World Health Organization.

8. World Health Organization, \& Research for International Tobacco Control. (2008). WHO report on the global tobacco epidemic, 2008: the MPOWER package.

9. Peraturan Bupati Bantul Nomor 18 tahun 2016 tentang Kawasan Sehat Bebas Asap Rokok

10. Peraturan Menteri Pendidikan dan Kebudayaan Nomor 64 tahun 2015 Tentang Kawasan Tanpa Rokok Di Lingkungan Sekolah.

11. Riskesdas. Laporan Nasional Riset Kesehatan Dasar. Jakarta: Kementerian Kesehatan RI 2010.

12. Puswitasari, A., Santosa, S., \& Wijayahadi, N. (2012). Faktor Kepatuhan Mahasiswa dan Karyawan Terhadap Peraturan Kawasan Tanpa Rokok di Lingkungan Kampus Fakultas Kedokteran Universitas Diponegoro.

13. Parks, T., Wilson, C. V., Turner, K., \& Chin, J. W. (2009). Failure of hospital employees to comply with smoke-free policy is associated with nicotine dependence and motives for smoking: a descriptive cross-sectional study at a teaching hospital in the United Kingdom. BMC Public Health, 9(1), 238.

14. Notoadmodjo S. Promosi Kesehatan dan Ilmu Perilaku. Jakarta: Rineka Cipta; 2007.

15. Winarno, B. (2012). Kebijakan publik: teori, proses, dan studi kasus: edisi dan revisi terbaru.

16. Widodo, Joko. 2017. Analisis Kebijakan Publik, Konsep dan Konsep dan Aplikasi Analisis Proses Kebijakan publik. Malang : Media Nusa Creative

17. Suharno. 2013. Dasar-Dasar Kebijakan Publik; Kajian Proses dan Analisis Kebijakan.Yogyakarta: Ombak

18. Nurfita, D., Rokhmayanti, R., Agustin, H., \& Sugathan, S. (2019). The Evaluation Of A Smoke-Free Area Declaration Program To Create A Healthy City At Puskesmas Gondokusuman. Epidemiology and Society Health Review (ESHR), 1(1), 41-50. 